\title{
William Morris and John Dewey: Imagining Utopian Education
}

\section{John Freeman-Moir}

\begin{abstract}
With striking resonance, William Morris and John Dewey independently imagined what utopian education might plausibly be. Neither remotely thought of utopia as a perfectly ordered society, but rather as a process. Each understood education functionally in terms of how it fits with art, work, and democracy within a holistic conception of utopia. Their projections of utopian education envisage societies in which ends and means are integrated, and where useful productivity, pleasure, and rest are the reasonable achievements of all. Starting out from similar criticisms of education in class society, Morris and Dewey were utopian in ways that remain relevantly interesting.
\end{abstract}

\section{Introduction}

The houses on the opposite bank are very ugly. They remind me of children crying over an arithmetic lesson. ${ }^{1}$

-William Morris, The Poet as Printer

A divided world, a world whose parts and aspects do not hang together, is at once a sign and a cause of a divided personality. $^{2}$

-John Dewey, Experience and Education

Ugly environments-meaningless lessons-fractured personalities: these among other phenomena signaled for William Morris and John Dewey the impossibility of class-divided society providing for true or liberating education. A large literature on social inequalities and class differences has subsequently established, beyond 
reasonable doubt, that much in capitalist education is harsh, divisive, and distorting. This conclusion can be cursorily summarized by noting just a few well-known titles from the past half century: The Hidden Injuries of Class; Death at an Early Age; Schooling in Capitalist America: Educational Reform and the Contradictions of Economic Life; Learning to Labour: How Working Class Kids Get Working Class Jobs; Ghetto Schooling; Savage Inequalities. ${ }^{3}$ Educational injury, death, and savagery continue apace in our century. About this outcome both Morris and Dewey would, undoubtedly, be deeply disappointed. However, in the context of globalized capitalism's class structures and fissures neither would, perhaps, be particularly surprised.

This essay examines utopian education, or, more precisely, the imagination of utopian education, through the eyes of William Morris (1834-1896, artist, poet, preeminent designer and pattern maker in Victorian England, printer, and political activist) and John Dewey (1859-1952).

Morris almost certainly knew nothing of Dewey. Dewey referred only briefly to Morris. ${ }^{3}$ Comparisons, en passant, have been made between Morris and Dewey. Alan Ryan imagines that Dewey could quite easily have been a disciple of Ruskin and Morris. Richard Sennett remarks that "Dewey was a socialist in just the way John Ruskin and William Morris were: all three urged workers to assess the quality of their work in terms of shared experiment, collective trial and error." ${ }^{3}$ Despite differences in experience, thought and politics, their respective educational viewpoints-arrived at independently and at different times-are strikingly resonant. Morris and Dewey-each radical in his conception of how art, work, democracy, and education might be interwoven-imagined ways of living that would be radically more desirable than that which capitalist civilization and culture can provide for, and that each thought could be realizable. This is the holistic strain of utopianism that is to be found in both thinkers.

The resonance just noted between Morris and Dewey stems from their belief that utopian experience is crafted and is thus a matter of practice. Both understood that through experience we are deeply implicated in and part of the world and that everything we do develops through the actions we take. Morris, probably less familiar than Dewey to readers of this journal, reached his conclusions about experience and utopia as a practicing artist and craftsman. His view deepened and radicalized as a consequence of his commitment to practical socialist politics during the last decade of his life. Dewey's constantly evolving pragmatism found its orienting standpoint in everyday, purposeful human action and activity. Committed to the concrete possibility of craftsmanship and artfulness in ordinary human affairs, Morris and Dewey searched for integration and continuity in human experience. Each understood that what is crafted is done with care and that the crafted artefact-whether object, conversation, or institution (e.g., a lesson, a "school," a factory or cityscape)_embodies this care.

Neither Morris nor Dewey ever contended that utopia is an ideal fixed-state society of perfection, or that it could promise unalloyed happiness and a colorless 
end to history. On the contrary, utopia is a process the outcomes of which cannot be guaranteed and, therefore, the role, for example, of fate, suffering, and tragedy in human affairs must be taken into account. From this point of view utopian thinking is neither an exercise in futile dreaming nor is it nostalgia for a world or theoretical system that has been lost. Instead, utopian thought aims at what Ruth Levitas refers to as the imaginary reconstitution of society and it is best understood as method. Thus, utopianism is less concerned at the theoretical level with specific policy recommendations than with the education of the imagination, an education in conceiving alternative modes of life-imagination as hypothesis rather than as the provision of static blueprints. ${ }^{5}$ In this respect, an evident experimentalism and lack of dogmatism marks out their understandings of experience. As approached by Morris and Dewey the utopian process, as a matter of course, acknowledges the contingent, the prosaic, the tentative, and the provisional in human affairs. In words that I think both Morris and Dewey would admire, utopian experience and education can be said to be crafted from "things with which [we are] familiar, simple things ... recognizable as the things touched by the hands during the day ... All drawn with admirable simplicity and excellent design—all a unity—." These words express a common attitude that marks their respective approaches to utopianism and utopian education.

Superficially, it might appear that the essence of Morris's utopian imagination is very different from Dewey's, by virtue of being pictured in considerable detail in his novel News from Nowhere. This, however, overlooks the deeper truth that, as noted above, both Morris and Dewey take a developmental view of life. Morris understood human development within a materialist view of history as class struggle, while Dewey understood it in terms of the creativity of action understood pragmatically. In each case, their utopian inclinations were firmly grounded in this world and our actions, not in some more idealized or spiritualized world. Morris counseled the necessity of taking note of real historical movement and he dedicated a long chapter in Nowhere to how the change towards utopia came about. In Democracy and Education, in the famous chapter on the democratic conception of education, Dewey starts out from the position that the project of human development is not a matter of setting up some conception of an ideal society, but of crafting the future out of what we are now capable of doing and envisioning. The project of this essay is to emphasize just these points of similarity and the ways in which Morris and Dewey can both be seen as utopian in a perfectly intelligible sense. While not denying differences between Morris and Dewey, I am inclined to see these as secondary. In any event, this is a larger question and worthy of more detailed examination in its own right, though beyond the scope of this discussion.

Analyzing consummatory experience and, by implication, well-designed modes of life more widely, Dewey, in Art as Experience, might be taken to speak for them both with respect to the utopian disposition as expressed in education: "The problem of conferring esthetic quality upon all modes of production is a seri- 
ous problem. But it is a human problem for human solution ... In a better-ordered society than that in which we live, an infinitely greater happiness than is now the case would attend all modes of production. We live in a world in which there is an immense amount of organization, but it is an external organization, not one of the ordering of a growing experience, one that involves, moreover, the whole of the live creature, toward a fulfilling conclusion."7 Morris and Dewey think that education can only be grasped in relation to society understood as a whole: specifically, that democracy is educative; that utopia is a process and, correlatively, that utopian experience is historical. Both imagined utopias where citizens are endeavoring to live democratically and artfully in educationally sensitive environments.

For Morris and Dewey utopia is a society in which, under conditions of equality, the development of each is the condition for the development of all, and where experience is holistic, productive, pleasurable, and restful. Holistic conveys a sense of integration and continuity in utopian experience-as embodied in artefacts, landscapes, built environments, and social relations. Productive, in the widest sense, points to what people usefully do and artfully make in everyday life. Pleasure is the sense of experience fulfilled and rounded out, while restful refers to time for leisure, reflection, and renewal. Utopia is the interweaving of these elements in experience. In a comment on Dewey, but equally applicable to Morris, Ryan illustrates the point about the interwoven nature of utopian experience-that is, the reflective integration of means and ends-as follows, "It is easy to suggest that we live the way we do because we are engaged in instrumental activities: We drive on clogged highways not for its own sake but to get to work... Dewey denied that the ugliness of life and work [and education] was the result of a conflict between instrumental goods and ideal ends, as if handsome train stations and clean streets that give us pleasure as we walk them were a vain hope; it was rather a failure to think hard enough about enough of the consequences." The educational problem to be solved in utopia is how to integrate education and society from the beginning as a matter of internal organization, such that means and ends are woven together in experience.

What then, in the views of Morris and Dewey, is education in the utopian grain? Before taking up this question, let us first allow Morris and Dewey to state their objections to capitalist education. In the $1880 \mathrm{~s}$, Morris arrived at a version of what contemporary educational sociologists have commonly called the correspondence principle. Dewey had done the same by the early 1900s. In brief, the principle states that there is a determinant link between the social relations of production and the social relations of education. Education develops forms of social-class identification and values which adjust the learner to work relations and the wider structures and cultural milieu of class society. Applied to capitalism, the principle has been taken as the foundation of a radical critique of education and it points to the necessity of a classless society if education is to be of, by and for everyone. ${ }^{9}$ As Morris states it:

At present all education is directed towards the end of fitting people to take their places in the hierarchy of commerce-these as masters, those as 
workmen. The education of the masters is more ornamental than that of the workmen, but it is commercial still; and even at the ancient universities learning is but little regarded, unless it can in the long run be made to pay. Due education is a totally different thing from this, and concerns itself in finding out what different people are fit for, and helping them along the road which they are inclined to take. ${ }^{10}$

People are "educated" to become workmen or the employers of workmen, or the hangers-on of the employers; they are not educated to become men. With this aim in view, the conditions under which true education can go on are impossible. For the first and most necessary of them are leisure and deliberation; and leisure is a thing which the modern slaveholder will by no means grant to his slave as long as he grants him rations; when the leisure begins the rations end. Constant toil is the only terms on which they are to be had. Capitalism will not allow us the leisure, either for education or the use of it. Slave labor and true education are irreconcilable foes, for the latter means the continuous and duly balanced development of our faculties, whether in the school, the workshop, or the field. ${ }^{11}$

Clearly, Morris thinks that education in capitalist society does not, and cannot, constitute true or liberal education. This impossibility includes the forms of education available to children from those classes with wealth and power; elite education divides the experience of these children from the rest of society. The learning and life opportunities of working-class children are radically diminished in a capitalist society. These outcomes are, in part, the functions of education. More than a century later-notwithstanding enlightened intentions, intelligent theories of child development, a plethora of policy settings and subtle experiments in teaching-class inequalities in liberal capitalist societies, as well as inequalities of gender, ethnicity and disability are still deep and injurious. We may have advanced beyond the philistine narrowness of Mr. M'Choakumchild's educational practice to which Morris alludes_ "murdering the innocents" in Charles Dickens's memorable phrase-but utilitarian economics, in one version or another, continues to provide the dominant rationale for capitalist educational systems. The presumed benefits of increased productivity and competitive economic advantage are among the first justifications to be given for the educational policies that emanate from our boardrooms and schoolrooms. When economies falter and societies enter periods of crisis, education is typically called into question. ${ }^{12}$ Dewey gives the following account of correspondence:

The Utopians believed that the pattern which exists in economic society in our time affected the general habits of thought; that because personal acquisition and private possession were such dominant ideals in all fields, even if unconsciously so, they had taken possession of the minds of educators to the extent that the idea of personal acquisition and possession controlled the whole educational system. ${ }^{13}$ 
There is no favored class in history which has not suffered from distorted ideas and ideals, just as the deprived class has suffered from inertia and undevelopment ... Schools have been accommodated in a passive way to existing industrial conditions ... The result is the current dualism of a refined and remote culture on the one side and a harsh and inhumane vocationalism on the other. ${ }^{14}$

In an autocratically managed society, it is often a conscious object to prevent the development of freedom and responsibility; a few do the planning and ordering, the others follow directions and are deliberately confined to narrow and prescribed channels of endeavor. However much a scheme may inure to the prestige and profit of a class, it is evident that it limits the development of the subject class; hardens and confines the opportunities for learning through experience of the master class, and in both ways hampers the life of the society as a whole. ${ }^{15}$

If Morris were to read Dewey's assessment, he might well ask about the members of any social class, "how could they be better than the age that made them?"16 Morris and Dewey's educational utopias are their ways of replying to this question. Respectively, the Morrisian and Deweyan projects of utopian education, and of utopia more widely, were to imagine forms of life in which useful productivity, pleasure, and rest is the achievement of all. The second section of this essay examines aspects of Morris's craft of utopian education while the third section turns to Dewey's sketch of creative democracy as utopian education.

\section{An Educationally Artful Utopia}

Education means reasonable, pleasant work, and beautiful surroundings, and unanxious leisure, these are essential parts of it. ${ }^{17}$

\section{-William Morris, Art and Labour}

"Nowhere," is the name of Morris's utopia. It is a classless society, in which an unhurried educative way of living allows children and adults the space and time to consider consequences and develop "their real capacities," whatever "their varying faculties and dispositions might be"-under conditions of utopian equality. Old Hammond, the historian in Nowhere, remarks that, "we can afford to give ourselves time to grow." 18 We catch here a sense of Jean-Jacques Rousseau's celebrated claim that the most important rule of all education, "is not to gain time but to lose it."19

Whatever more extensive and detailed forms of organization and administration may be required, the utopian way of life depends, at its core, on participation and face-to-face forms of association and administrative decentralization. Morris took this view because he saw it as a way to "give all . . . a share in the responsibility of the administration of things which I hope will take the place of the govern- 
ment of persons ... I admit that the form which the decentralization ... will take is bound to be a matter of experimentation and growth." ${ }^{20}$ In other words, utopia is a form of education based on democratic participation. Morris, perhaps, first came to understand this point through his own educational work in the English socialist movement of the late nineteenth century. He thought that the mutual expression of ideals, speculations, hopes, and fears "will make us know each other better ... make us better friends." ${ }^{21}$ We have here an intimation of a way of life to which education is integral, and it is worth noting that "friend" and "neighbor" are the common terms of greeting in Nowhere. This calls to mind Dewey's later conception of creative democracy as the "free gatherings of neighbors." 22 Morrisian democracy is an organization of communes. On any issue the members of the commune come together for discussion and then voting. Time is given for all members to consider the issues and if the voting is close further meetings can be called. Guest, the visitor to Nowhere, finds out that the differences which separate people are about "business and passing events" and these are not generally of the kind thought to "divide men permanently." ${ }^{23}$ Morris takes the view that in a community of people who are free and equal, "the apparent majority is the real majority." ${ }^{24}$

An anti-utopian alternative could be, in Morris's view, a Platonic “aristocracy of intellect ... a class of superior persons capable of judging on all matters without consulting the neighbours." ${ }^{25}$ Morris objects that this elitism would destroy the equality of condition and freedom necessary to the development of a richly varied social individuality. While not denying the biological foundations of human development, he rejects the notion that social class, political conflict, and selfishness are expressions of a biologically irredeemable human nature, rather than the outcomes of social conditions. As Old Hammond exclaims, "what human nature? The human nature of paupers, of slaves, of slave-holders, or the human nature of wealthy freemen." 26

Morris expresses a view that Dewey also gives voice to when he refers to utopian education as overcoming those "artificial disabilities ... which make ... children something less than men and women," thereby allowing children to "live and act according to the measure of their own faculties." ${ }^{27}$ Freed from economically driven educational competition, utopia seeks to have every individual "exercise his special faculty to the utmost, and every one encourages him in so doing." ${ }^{28}$ Old Hammond refers to this as the utopian "tradition or habit ... of acting on the whole for the best." 29 From an educational perspective, utopia is a framework of human development which supports a "variety of life ... [and] real freedom." ${ }^{30}$ Morris, like Dewey, understands utopia pragmatically as educative and developmental, "a matter of experiment and growth." ${ }^{11}$ How might this achieved?

For Morris, utopia opens people outwards to the "the sensuous pleasures of life," not as diversions or forms of escapism, as if the world were "an impressionist picture" or "a ruinous piece of picturesque," but by a full engagement in "the goings on in the field and flood and sky," a pleasurable interest in all the details of ordinary 
life. ${ }^{32}$ The reunification of the mental and the manual is a first step in the utopian experiment: "We shall not be happy unless we live like good animals, unless we enjoy the exercise of the ordinary functions of life: eating, sleeping, loving, walking, running, swimming, riding, sailing, we must be free to enjoy all these exercises of the body without any sense of shame; without any suspicion that our mental powers are so remarkable and godlike that we are rather above such common things." ${ }^{33}$ This celebration of physical activity, habits, and skills reminds us of the origins of sensorimotor development in children, where the mental and the manual are unified and where making is thinking. Educationally, utopia requires environments and social relations that support continuity and integration in experience across the lifespan and between generations.

Morris's argument with respect to the facilitating conditions for the craft of utopian experience is straightforward. An equality of condition is the solution to an equitable share of wealth and to solving relations between worthwhile and pleasurable work, rest, and leisure. If all people produce and work is not wasted, then all will have the hope of sharing wealth and none will miss out on their share of rest. Utopian equality sustains individual human development and education in a way that does not compromise the opportunity of others to develop. Commenting on a similar argument in Dewey, but equally applicable to Morris, Ruth Anna Putnam notes that "all this makes one's own and everyone else's capacities available for the common good." 34

Useful work should be done under conditions where the worker is assured that rest, "when it comes, must be long enough to allow us to enjoy it; it must be longer than is merely necessary for us to recover the strength we have expended in working, and it must be animal rest also in this, that it must not be disturbed by anxiety, else we shall not be able to enjoy it." ${ }^{35}$ Morris argues that rest linked to equality of work frees the worker from the forced stresses and anxieties associated with class society. With adequate leisure people will have time to participate in a variety of activities, to enjoy each other's company, to be idle, to dream. Morris thinks that work itself would begin to take on the quality of restfulness. He concludes that, "such a holiday our whole lives might be."36

Pleasure, in addition to worthwhile production and rest, is the third element in Morris's understanding of the relation between work and education. The hope of pleasure, he maintains, opens activity up to the possibility of living more fully. Pleasure describes experience which is fulfilled-in work as well as in the enjoyment of consummatory activities. In resonance with Dewey, Morris notes that pleasurable activity connects the past, present, and future in experience:

The hope of pleasure in the work itself: how strange that hope must seem to some of my readers - to most of them! Yet I think that to all living things there is a pleasure in the exercise of their energies, and that even beasts rejoice in being lithe and swift and strong. But a man at work, making something which he feels will exist because he is working at it and wills 
it, is exercising the energies of his mind and soul as well as of his body. Memory and imagination help him as he works. Not only his own thoughts, but the thoughts of the men of past ages guide his hands; and, as a part of the human race, he creates. If we work thus we shall be men, and our days will be happy and eventful. ${ }^{37}$

As a practicing craftsman Morris made a number of proposals designed to ensure that pleasure is a part of work: first, work should be useful to the needs of people (in contrast to production determined by profit and financial return to investors, with scant regard to need); second, where work is burdensome its duration should be shortened as much as possible, relieved by machines or eliminated altogether; and third, work should involve variety. Morris thinks that in utopia, a person "might easily learn and practise at least three crafts, varying sedentary occupation with outdoor occupation." ${ }^{38}$ In language that anticipates a central theme in Dewey, Morris links variety in work to utopian education, "due education . . . concerns itself in finding out what different people are fit for," and, as we have already heard from Morris above, "helping them along the road which they are inclined to take." ${ }^{39}$ In Nowhere, people become more expressive in their work and life becomes more artful; "the origin of this art was the necessity that the workman felt for variety."

Finally, Morris proposes that work be done in pleasant and beautiful surroundings; "there is no reason why they should not follow their occupations in quiet country homes, in industrial colleges, in small towns, or, in short, where they find it happiest for them to live. ${ }^{{ }^{41}}$ In A Factory As It Might Be Morris pictures a working environment sympathetically set in pleasantly landscaped gardens where work is expected to provide for a "life rich in incident and variety." ${ }^{2}$ Significantly, education is at the center of the factory, providing an introduction to life skills for children and continuing education for adults. Work is to be artful and will lead to a "love of art," workers will have the opportunity and want to study their respective crafts, and in their wider lives "voluntary work may be varied by the study of general science or literature." ${ }^{33}$ A factory will, "as a matter of course, find it easy to provide for more restful amusements, as it will have ample buildings for library, school-room, dining hall, and the like; social gatherings, musical or dramatic entertainments will obviously be easy to manage under such conditions." ${ }^{\prime 4}$ Morris imagines that the factory will foster "intelligent interest" and that "persons [who], either by themselves or associated for such purposes, would freely ... produce... ornaments of life for the service of all." ${ }^{\prime 4}$

As Morris imagines them, utopian forms of social organization will allow time for people to consider and deliberate, to pursue individual interests and delight more easily in "the details of life." ${ }^{36}$ People will "look around and consider what [they] really want." ${ }^{\prime 7}$ As already mentioned, the holiday is taken as a metaphor of utopian experience, thereby allowing adults and children to, "unhurriedly, thoughtfully, and happily ... note the course of [their] lives amidst all the little links of events which connect them with the lives of others, and build up the great whole of humanity." ${ }^{38}$ 
Considered educationally, the end-in-view of utopian experience is "to build up the ornamental part of life-its pleasures, bodily and mental, scientific and artistic, social and individual - on the basis of work undertaken willingly and cheerfully, with the consciousness of benefiting ourselves and our neighbours by it." ${ }^{39}$ In contrast to a patchwork of polluting factories, ill-designed urban and rural spaces and ugly houses (an instance of Dewey's divided world whose parts do not hang together), Morris describes an environment designed to sustain continuity and fulfillment in the activities and experience of children-places "of peace and rest, and cleanness and smiling goodwill." ${ }^{50}$ In the twenty-first century this remains a relevant standard by which to judge spaces for children and adults in cities, towns, and the country.

On his visit to Nowhere, Guest sees something of how child development and education are woven into the design of utopia. Children are not required to commence school at a legally (i.e., arbitrarily) determined age, regardless of their interests and dispositions, nor are they made to conform to a curriculum that may have little relevance to their development. Guest is told that conventional learning "means ignoring the fact of [a child's] growth, bodily and mental ... all that is past; we are no longer hurried and the information lies ready to hand when his own inclinations impel him to seek it." ${ }^{51} \mathrm{He}$ also observes children camping, an activity which is encouraged in utopia because "they learn to do things for themselves, and get to notice the wild creatures ... [and] it gives them a little rough work." ${ }^{2}$ Guest discovers that this is not just a bit of summer camping for children before school recommences but a central part of their skill development; skills in disciplines like thatching, training a horse, carpentry, cooking, house building, gardening, and street paving. And Guest is pointedly reminded not to "run away with the idea that it doesn't take some skill to do them, and doesn't give plenty of work for one's mind." ${ }^{3}$ Children need time to develop sensorimotor skills and habits of work through imitating adults who they see "engaged in genuinely amusing work." ${ }^{54} \mathrm{~A}$ developmental conception of experience and education is not just a contingent fact about utopia, but is instead constitutive of its deepest organizing principles.

Sounding rather Deweyan, Morris's underlying view of utopian education is that "tis no use forcing people's tastes" because children will come to "live and act according to the measure of their own faculties." ${ }^{55}$ Guest worries about the intellectual aspects of education but, to the utopians, this rather misses the point as his tour guides, with only partial success, try to show him. Rather than reading, writing, mathematics, and languages being overlooked (e.g., utopians are multilingual), it is made clear to Guest that the aim is to discourage an "early bookishness" ${ }^{56}$ which would be at the expense of holistic experience to which particular skills and areas of knowledge will contribute. Indeed, "many people study facts about the make of things and the matters of cause and effect, so that knowledge increases on us." Guest concludes, in fact, that utopian education is a mistakenly one-sided version of what later came to be known as child-centered progressivism, the very version that Dewey famously disowned; "I gathered ... that you let your children run wild 
and didn't teach them anything, and in short, that you have so refined your education, that now you have none." ${ }^{58}$ This version of child-centered education is contrasted with what Dewey calls conventional education in which authorities decide what children should learn. The principal objective of this conventional education is to prepare children for living. As Old Hammond perceptively observes, "this is pinched 'education' . . . something to be swallowed by the beginner in the art of living whether he liked it or not ... No one could come out of such a mill uninjured." ${ }^{59}$ Conventional education corresponds to the instrumental requirements of the economy. "The whole theory of their so-called education was that it was necessary to shove a little information into a child ... or else he would lack information lifelong: the hurry of poverty forbade anything else." ${ }^{60}$ By contrast, utopia requires a form of education that allows children to live and participate in an environment which gives them time to grow. This is the premise that underpins Morris's view of utopia as educative and Dewey's educational understanding of creative democracy. Far from being unthinkingly child centered, as if everything in development emerges spontaneously from the mind and the body of the child, utopian child development is part of the fabric of society from the beginning. And this fact is no more evident than in how utopia arranges the continuities between work, community, and environment, which Morris alludes to in the epigraph at the head of this section.

\section{Creative Democracy: An Educational Utopia}

I believe that education, therefore, is a process of living and not a preparation for future living. ${ }^{61}$

\section{-John Dewey, My Pedagogic Creed}

In utopia, democracy must, to borrow a phrase, "nestle everywhere, settle everywhere, establish connections everywhere."62 In 1939, Dewey offered a sketch of utopia entitled Creative Democracy - The Task before Us. Reaching beyond the machinery of electoral mechanism, Dewey proposes "that democracy is a way of life," and even further, "that it is a personal way of individual life ..." ${ }^{63}$ In a reverberation of Morris's utopianism Dewey indicates,

I am inclined to believe that the heart and final guarantee of democracy is in free gatherings of neighbors on the street corner to discuss back and forth what is read in uncensored news of the day, and in gatherings of friends in the living rooms of houses and apartments to converse freely with one another. Intolerance, abuse, calling of names because of differences of opinion about religion or politics or business, as well as differences of race, color, wealth or degree of culture are treason to the democratic way of life. For everything which bars freedom and fullness of communication sets up barriers that divide human beings into sets and cliques, into antagonistic sects and factions, and thereby undermines the democratic way of life. ${ }^{64}$ 
Of course, there will be conflicts and differences of viewpoint in utopia, but they will not be expressive of systemic forms of subordination and social exclusion. Dewey's description evokes a sense of the utopian process as constituted by federations of communities of a relatively small size, and as depending on maximum freedom and openness of communication in everyday matters. Forms of action, habit, and pleasure will be widely understood and identified as the recognizable customs and traditions of people, "controlled by personal faith in personal day-by-day working together with others." 65

This mode of life is based on the concrete and active capacity of human beings to undertake self-corrective judgements and actions; individually and cooperatively. For Dewey, utopian education is correlated with this capacity, which is why creative democracy places a premium on participation, discussion, and exchange, and engagement with the facts, beliefs, and ideas of everyday life. In the utopian imaginations of Morris and Dewey democracy goes all the way down. Given a context of substantive equality, Dewey notes the potential for differences and conflicts between citizens to enhance utopian culture. In the face of difference, mutual discussion is the means by which, through "the habit of amicable cooperation ... [we] treat those who disagree-even profoundly-with us as those from whom we may learn, and in so far, as friends." ${ }^{66}$ Dewey draws the important conclusion that, "to cooperate by giving differences a chance to show themselves because of the belief that the expression of difference is ... a means of enriching one's own life-experience, is inherent in the democratic personal way of life." ${ }^{67}$ This is what it means to say that democracy is educative.

Utopia requires the possession of certain attitudes, habits, dispositions, and purposes across and within "all the relations of life." ${ }^{68}$ Dewey characteristically turns the conventional understanding of democracy on its head. "Instead of thinking of our dispositions and habits as accommodated to certain institutions we have to learn to think of the latter as expressions, projections and extensions of habitually dominant personal attitudes." ${ }^{99}$ At root, democracy rests on a "working faith in the possibilities of human nature,"70 a faith which is nondiscriminatory across all citizens. Deweyan democracy is a culture shaped by the possibilities open to every citizen and this requires conditions that enable the development of capacities for "intelligent judgement and action" in every member of the community, "whatever gifts he has." 71

Utopia, as should be clear, is a society open to experiment and revision in the light of experience, based on the habit of thinking rigorously and practically about enough of the consequences. For Dewey, utopia is a culture in which communities endeavor to learn forwards to consequences and backwards from them to new needs and solutions. Utopian education is, therefore, "the free interaction of individual human beings with surrounding conditions ... which develops and satisfies need and desire by increasing knowledge of things as they are ... [in order] to open the road and point the way to new and better experiences." 72 If education 
is a process of living, as Morris and Dewey insist, then utopian education must be intimately integrated with the rest of society at every point. In the first instance, it is this that, as with Morris, defines Dewey's holistic view of utopian education. An analysis of the details of curriculum and teaching appropriate to a Deweyan utopia lies beyond the scope of this essay.

In Utopian Schools, Dewey reports on an imaginary visit he made to a place called Utopia. He begins by announcing that "the most Utopian thing in Utopia is that there are no schools at all." ${ }^{73}$ Guest, it will be recalled, also found an absence of schools in Nowhere. This conceit expresses an allergy shared by Morris and Dewey to schools as they observed and experienced them. Morris called schools "boy-farms," and Dewey stated that "the primary waste is that of human life, the life of children while they are at school, and afterward because of inadequate and perverted preparation." ${ }^{74}$ What, then, did Dewey find in Utopia?

Children of all ages are brought together with adults who have a directive role. These assembly places or "schools" are set in expansive grounds which include gardens, orchards, and greenhouses and which reach out beyond, to fields, rivers, and forests. The limit on the number of people in any school is about two hundred, a number which is thought to approximate the limits on face-to-face contact in an association. The architecture of the educational centers opens out to the environment and they are furnished with equipment for working on materials such as wood, metal, and fabrics. Associated with the school are museums, laboratories, and libraries. The adults have all had experience of children by being parents, and younger people who act as assistants will typically undergo an apprenticeship in educational practice. The classes are not arbitrarily organized by age and older children work with younger children. Consequently, "it soon becomes evident who among them have the taste, interest and the kind of skill which is needed for effective dealing with the young." ${ }^{2}$ This is a model of education appropriate to learning environments where real activity and real experience reveals interests in work. Parents who have a particular interest in education can engage with larger groups of children as their contribution to the utopian community.

Words like school, teacher, pupil, and lesson have little or no meaning for the utopians, and Dewey's question about the objectives of the centers puzzles them. They point out that there are no objectives "beyond the process of developing life."76 Translated into the work of the centers this idea means discovering "the aptitudes, the tastes, the abilities and the weaknesses of each boy and girl" and developing these capacities into attitudes, habits, and positive powers, "so as not to cover up the weak points but to offset them." In response to Dewey's question about subject matter and disciplines the utopians are equally puzzled. How is it possible for children "to grow up without learning the things which ... needed to be learned-because it was evident to them that it was not possible for any one ... to be born and to grow up without learning." ${ }^{78}$ Dewey's hosts even wonder if, before Utopia, it was true that there were schools, teachers, and standards to ensure that infants learned 
the skills of walking and talking! Reflecting on these questions, Dewey appreciates "how completely the whole concept of acquiring and storing away things had been displaced by the concept of creating attitudes by shaping desires and developing needs that are significant in the process of living."79

With the help of the utopians, Dewey is led towards an appropriately utopian account of correspondence. The competitive methods, rivalries, systems of rewards and punishments, formal examinations, and systems of promotion in schools, are "the kind of measure and test of achievement and success which had to prevail" in capitalist society with its imperatives of economic competition, acquisition, and control. ${ }^{80}$ The transition beyond "acquisitive economic society . . . made possible the transformation of the center of emphasis from learning (in our sense) to an education devoted to the creation of attitudes [and] . . . to finding out the conditions of the environment and the kinds of activity in which the positive capacities of each young person could operate most effectually." ${ }^{\prime 1}$ Echoing Morrisian themes, creation and useful productivity, not acquisition, become the centers of children's education. With the integration of work and pleasure, the utopians "said that there is no genuine production without enjoyment ... and the only education that really could discover and elicit power was one which brought these powers for immediate use and enjoyment." 82 In pursuing the "all-around development of the capacities of the young," utopian education gives children a sense of power expressed in such attitudes and habits as confidence, readiness to tackle obstacles, and an eagerness to search out problems. ${ }^{83}$ Dewey concludes that in Utopia, education "included a faith in the capacity of the environment to support worthwhile activities, provided the environment was approached and dealt with in the right way." ${ }^{44}$

The core idea of My Pedagogic Creed - that education is a process of livingdefines the essence of Dewey's educational utopianism. If education is living, then it can only be realized through the participation of children and adults in communities where democracy, committed to the ends of freedom and equality, is complete. Creative democracy is Dewey's equivalent to Morris's condition of equality-the habit of acting in terms of the whole for the benefit of all. The continuities of utopia require, then, that children's development occur in communities where "a spirit of free communication, of interchange of ideas, suggestions, results, both successes and failures of previous experiences, [is] the dominating note." 85

Like Morris, Dewey speaks too of the educative process and the child as a "single whole-heartedness." 86 This is contrasted with pre-utopian education that, with reference to the wider habitat of the child, separates the child, the curriculum, and the community, the consequence being, to "divide and fractionize the world for him." ${ }^{77}$ Seeking an answer to this problem of division and dualism in experience Dewey, like Morris before him, pays particular and generous attention to relations between education and work in utopia: "We must conceive of work in wood and metal, sewing and cooking, as methods of living and learning, not as distinct studies. We must conceive of them ... as types of the processes by which society keeps 
itself going, as agencies for bringing home to the child some of the primal necessities of community life ... as instrumentalities through which the school itself shall be made a genuine form of active community life, instead of a place set apart in which to learn lessons." ${ }^{88}$ Here, Dewey's view echoes almost exactly the observations of Morris about the development of utopian children.

The following montage, drawn from The School and Society, shows just how close Dewey and Morris are in their educational utopianism:

[The "school"] has a chance to affiliate itself with life ... to be a miniature community, an embryonic society, [where] ... the aim is not the economic value of the products, but the development of social power and insight ... Knowledge is no longer an immobile solid; it has been liquefied. It is actively moving in all the currents of society itself, [and] ... when the school introduces and trains each child of society into membership within such a little community, saturating him with the spirit of service, and providing him with the instruments of effective self-direction, we shall have the deepest and best guaranty of a larger society which is worthy, lovely, and harmonious. ${ }^{89}$

\section{Conclusion}

While visiting Nowhere, Guest comes to understand that "the reward of labour is life [itself]," not some kind of external reward, and this follows from a form of life in which "conscious sensuous pleasure" is part of it all. ${ }^{90}$ Similarly, Dewey held that the development of children within a society that interweaves productivity, pleasure, and rest, is a process of living in which experience is crafted as ends and as means. Morris characterized this outcome of utopian life as joy; Dewey spoke of it as wholeheartedness.

At the end of the first decade of this century there is plenty to be disenchanted and disheartened about, including forms of education and democracy evident in capitalist society. And it is commonplace to think that while the hope for more humane alternatives is understandable it is also, in a dismissive sense of the word, "utopian." Morris and Dewey stand for opposition to such dismissive usage. In 1939, Dewey mentioned just such a criticism leveled against himself, that he was naïve, and that he had an undue utopian faith. He replied simply, by reasserting his faith in the common person and the radical potential of democracy. And he noted that his utopianism was acquired from ordinary daily surroundings and activities. Morris was familiar with similar criticisms towards the end of his life. Again, I allow Dewey to speak for them both, for in so speaking he imaginatively projects the widest possible linkages between democracy, education, and daily experience. As Dewey puts it:

For what is the faith of democracy in the role of consultation, of conference, of persuasion, of discussion, in the formation of public opinion, which in the long run is self-corrective, except faith in the capacity of the intelligence of the common man [the common woman, the common young person, 
and the common child] to respond with commonsense to the free play of facts and ideas which are secured by effective guarantees of free inquiry, free assembly and free communication... Since the process of experience is capable of being educative, faith in democracy is all one with faith in experience and education. All ends and values that are cut off from the ongoing process become arrests, fixations. ${ }^{91}$

It is here that we find the source of the kind of advice that our two utopians might wish to urge upon us. It is not an offering of specific policies or technical fixes to this or that particular problem in the name of a spurious realism, but an invitation to engage in an imaginative reconstitution of society and its modes of education, towards the end of opening up society to freer ways of living and association for all. For example, free education for all children in public schools would be a good place to start, though this demand would, no doubt, be worked out differently in different societies. The literature briefly referred to in the first paragraph, along with much other research, shows that anything less than utopian thinking will stifle the kinds of imagination now urgently required, leading to just those kinds of arrests and fixations that Morris and Dewey warned against. It is their earth-grounded visions that we can continue to learn from and value-resources that we can rework and rethink for our own purposes.

At the end of his life, and referring to artful activity, Dewey linked the elements of a holistic utopianism in a single sweep: "There is no inherent difference between fullness of activity and artistic activity; the latter is one with being fully alive. Hence it is not something possessed by a few persons and setting them apart from the rest of mankind, but is the normal or natural human heritage . . it provides the pattern and model of the full and free growth of personality and full life activity, wherever it occurs." 92 This is a view of utopian experience and education which supports the idea that everyone can be a craftsperson and an artist, and if that is the case then everyone can be a fully functioning member of a democratic society as well; a view that Morris, for mostly the same reasons, would have found immediately attractive. There are considerable obstacles in moving towards the kinds of ideals in education and experience that Morris and Dewey hold out, but this is no reason to disparage the ideals themselves or to give up on them. It is, however, a very good reason to examine these ideals and utopian projections carefully and critically.

At the beginning of this essay, we found Morris looking across the Thames. If Morris were to look again, he might see-standing in the grey light on the opposite bank-a simpatico utopian who understands "the foundation of our life and our happiness," and what must be done if children are to stop crying. ${ }^{93}$ Against the careless and rapacious utilitarian cultures of our market-drenched societies, the imaginative utopian conceptions of democracy, experience, and education suggested by Morris and Dewey are worthy of continued exploration, extension, and defense-as we, like they, ponder the question, "how shall we live then?"94 


\section{Notes}

1. Morris, “The Poet as Printer," 53.

2. Dewey, Experience and Education, 44.

3. Dewey referred to "literary socialists who cluster about William Morris." Dewey, “The Angle of Reflection,” 202. Dewey noted Ruskin's “denunciation of the entire reigning system of economics, theoretical and practical. The esthetic socialists of the school of William Morris carried his teachings home in the popular mind" (19). It is not known if Dewey read News from Nowhere or what, more precisely, he knew of William Morris. He did visit Brydcliffe, the arts and crafts colony in Woodstock, New York which was founded by Ralph Whitehead, a disciple of John Ruskin and Morris. This was a likely source of knowledge for Dewey about Morris and the arts and crafts movement more widely. In respect of utopian writing Dewey was familiar with Edward Bellamy's utopian novel Looking Backward (1888) which he reviewed favorably. William Morris was very critical of Bellamy's novel, regarding its utopian vision as mechanically routine and cramping.

4. Ryan, John Dewey and the High Tide of American Liberalism, 116. Sennett, The Craftsman, 288.

5. Morris touches on these topics in his utopian novel News from Nowhere (see note 16 below). Sidney Hook shows that Dewey had a sense of evil and the tragic in human life. See Hook, Pragmatism and the Tragic Sense of Life. For an argument which advances a process model of utopia with explicit reference to Dewey's pragmatism, see McKenna, The Task of Utopia. For a methodological approach to utopia, see Levitas, "The Imaginary Reconstitution of Society: Utopia as Method," 47-68.

6. William, Imaginations, 110.

7. Dewey, Art as Experience, 80.

8. Ryan, John Dewey and the High Tide of American Liberalism, 238.

9. Bowles and Gintis in Schooling in Capitalist America were the first to enunciate the correspondence principle under this name.

10. Morris, "Useful Work versus Useless Toil," 300.

11. Morris, "Thoughts on Education Under Capitalism," 377.

12. As a typical example, see this comment from the New York Times, July 27, 2010: "With the economy still terribly weak, many people are understandably unsure about the value of education. They see that even college graduates have lost their jobs in the recession. Barely a week seems to go by without a newspaper or television station running a report suggesting that education is overrated. These stories quote liberal groups, like the Economic Policy Institute, that argue that an education can't protect workers in today's global economy. Or they quote conservatives, like Charles Murray and Ramesh Ponnuru, who suggest that people who haven't graduated from college aren't smart enough to do so."

13. Dewey, "Dewey Outlines Utopian Schools," LW 9: 139.

14. Dewey and Tufts, Ethics, 386, 407.

15. Dewey, Democracy and Education, 311.

16. Morris, "News from Nowhere," 103.

17. Morris, "Art and Labour," 114.

18. Morris, "How We Live and How We Might Live," 157; Morris, "News from Nowhere," 97, 98. For an interesting account of education in Nowhere which places it in a literary context see, Ady Mimeo, "The Reverse of Salem House: the Holistic Process of Education in News from Nowhere," 6-16.

19. Jean-Jacques Rousseau, Emile or On Education, 93.

20. Morris, "How Shall We Live Then?" 233-34. 
21. Ibid., 222.

22. Dewey, "Creative Democracy-The Task Before Us," LW 14: 227.

23. Morris, "News from Nowhere," 118.

24. Ibid., 119.

25. Ibid., 120.

26. Ibid., 118. For an argument similar to Old Hammond's, but applied to John Dewey see, Ruth Anna Putnam, "Democracy as a Way of Life," 41.

27. Ibid., 95.

28. Ibid., 113.

29. Ibid., 112.

30. Morris, "Looking Back," 358.

31. Morris, "How Shall We Live Then?" 234.

32. Ibid., 227.

33. Ibid., 228.

34. Putnam, "Democracy as a Way of Life," 42.

35. Morris, "News from Nowhere," 288.

36. Ibid., 296.

37. Ibid., 288-89. For a point of comparison, consider Dewey on habits of work: "Their significance depends upon the environment inherited from our forerunners, and it is enhanced as we foresee the fruits of our labors in the world in which our successors live." Dewey, Human Nature and Conduct, 23. When Morris speaks of pleasure or joy in work he is not just referring to a subjective desire for feelings of satisfaction associated with artefacts and activities, but to the their actual satisfaction in the real world of objective conditions. Hilary Putnam has shown that Dewey takes the same position about pleasure in his Ethics. See note 14 above. Putnam, "Intelligence and Ethics," 267-77.

38. Morris, "Useful Work versus Useless Toil," 300.

39. Ibid.

40. Ibid., 301.

41. Ibid., 302.

42. Morris, A Factory as It Might Be, 11.

43. Ibid., 12.

44. Ibid., 13.

45. Morris, "Useful Work versus Useless Toil," 303.

46. Ibid., 296.

47. Ibid., 298.

48. Ibid., 296.

49. Ibid., 299.

50. Morris, "News from Nowhere," 44. The continuities and integrations of utopia, which give utopian experience its holistic nature, are fundamental educational themes in Morris's writing. For example, in A Factory as It Might Be, 7, he writes: "it follows in this garden business that our factory must make no sordid litter, befoul no water, nor poison the air with smoke." Elsewhere, in "Art a Serious Thing," 49, he observes: "the house shall be like a natural growth of the meadow, and the city a necessary fulfilment of the valley."

51. Morris, "News from Nowhere," 97-98.

52. Ibid., 65.

53. Ibid., 66.

54. Ibid., 68 .

55. Ibid., 68, 95. 
56. Ibid., 68. Dewey also opposed an early and excessive bookishness in the education of children as works like The School and Society and Schools of Tomorrow show.

57. Ibid., 68.

58. Ibid., 97.

59. Ibid., 97. Dewey, too, was well aware and critical of the wastage of human lives in capitalist education. See note 74 below.

60. Ibid., 97-98.

61. Dewey, "My Pedagogic Creed," EW 5: 87.

62. Marx and Engels, Manifesto of the Communist Party, 37.

63. Dewey, "Creative Democracy-The Task Before Us," LW 14: 226. On a number of occasions Richard Bernstein has offered illuminating and utopian comment on this essay of Dewey's. See, for example, Bernstein, The Pragmatic Turn, 70-88.

64. Ibid., 227.

65. Ibid., 228.

66. Ibid.

67. Ibid.

68. Dewey, “Dewey Outlines Utopian Schools," LW 9: 136.

69. Dewey, "Creative Democracy-The Task Before Us," LW 14: 226.

70. Ibid., 226.

71. Ibid., 227.

72. Ibid., 229.

73. Dewey, "Dewey Outlines Utopian Schools," LW 9: 136.

74. Morris, "News from Nowhere," 66; Dewey, "The School and Society," MW 1: 39.

75. Dewey, "Dewey Outlines Utopian Schools," LW 9: 137.

76. Ibid., 138.

77. Ibid.

78. Ibid.

79. Ibid., 139.

80. Ibid. Albert Einstein, who implicitly understood the correspondence principle, made the same criticism of capitalist education as Morris and Dewey. In, "Why Socialism?" 3, Einstein argues, "This crippling of individuals I consider the worst evil of capitalism. Our whole educational system suffers from this evil. An exaggerated competitive attitude is inculcated into the student, who is trained to worship acquisitive success as a preparation for his future career."

81. Ibid.

82. Ibid., 139-40.

83. Ibid., 140.

84. Ibid.

85. Dewey, “The School and Society," MW 1: 11.

86. Dewey, “The Child and the Curriculum," MW 2, 275.

87. Ibid., 274

88. Dewey, “The School and Society," MW 1: 10.

89. Ibid., 12, 17, 19-20.

90. Morris, "News from Nowhere," 123.

91. Dewey, "Creative Democracy-The Task Before Us," LW 14: 227, 229. For an antiutopian view of Dewey's utopianism see Sidorkin, "John Dewey: A Case of Educational Utopianism," 191-99. For a reply to Sidorkin which views Dewey as a "utopian reconstructionist" as opposed to Sidorkin's Dewey as "escapist utopian" see, Stemhagen, "Dewey as 
Utopian: Labor Versus Leisure, Mass Media as Democratic Education, and the Future of Public Schooling," Ibid, 200-03.

92. John Dewey, The Unfolding of Artistic Activity, x.

93. Morris, "News from Nowhere," 112.

94. Morris, "How Shall We Live Then?" 217.

\section{References}

Anyon, Jean. Ghetto Schooling. New York: Teachers College Press, 1997.

Bernstein, Richard J. The Pragmatic Turn. Malden, MA: Polity Press, 2010.

Bowles, Samuel and Herbert Gintis. Schooling in Capitalist America: Educational

Reform and the Contradictions of Economic Life. New York: Basic Books, 1976.

Einstein, A. "Why Socialism?” Monthly Review 1 (May 1949): 3-11.

Dewey, John. Art as Experience. 1934. New York: Capricorn Books, Putnam, 1958.

-_- Democracy and Education. 1916. New York: The Free Press, 1966.

-_- Experience and Education. 1938. New York: Touchstone, 1997.

- - - Foreword to The Unfolding of Artistic Activity: Its Basis, Processes and

Implications by Henry Schaeffer-Simmern, ix-x. Berkeley: University of

California Press, 1948.

_-_. Human Nature and Conduct. 1922. New York: Random House, 1957.

-_- John Dewey, The Collected Works, 1882-1953. Edited by Jo Ann Boydston.

Carbondale: Southern Illinois University Press, 1972-1985.

Dewey, John and Tufts, James. Ethics. 1908. New York: Henry Holt, 1932.

Hook, Sidney. Pragmatism and the Tragic Sense of Life. New York: Basic Books, 1974.

Kozol, Jonathan. Savage Inequalities. New York: Harper Collins, 1991.

Levitas, Ruth. “The Imaginary Reconstitution of Society: Utopia as Method." In

Utopia Method Vision: The Use Value of Social Dreaming, edited by Tom Moylan and Raffaella Baccolini, 47-68. Oxford: Peter Lang, 2009.

Marx, Karl and Engels, Frederick. Manifesto of the Communist Party. 1848. Peking: Foreign Languages Press, 1975.

McKenna, Erin. The Task of Utopia: A Pragmatist and Feminist Perspective. Lantham: Rowan and Littlefield, 2001.

Meier, Paul. "An Unpublished Lecture of William Morris, How Shall We Live Then?” International Review of Social History 16 (1971), 233-34.

Mimeo, Ady. "The Reverse of Salem House: the Holistic Process of Education in News from Nowhere." Journal of the William Morris Society 11 (Autumn 1994): 6-16.

Morris, William. "Art and Labour." In The Unpublished Lectures of William Morris, edited by Eugene D. LeMire, 94-118. Detroit: Wayne State University Press, 1969.

- - - A Factory as It Might Be. 1884. London: Twentieth Century Press, 1907.

_-_ . "How We Live and How We Might Live." In Political Writings of William Morris, edited by A. L. Morton, 134-58. London: Lawrence and Wishart, 1973. Bristol: Thoemmes Press, 1994. 
- - - "Looking Back." In News from Nowhere and Other Writing, edited by Clive Wilmer, 351-58. London: Penguin Books, 1998.

- - _. "News from Nowhere." In News from Nowhere and Other Writings, edited by Clive Wilmer, 41-228. London: Penguin Books, 1998.

_-_ . "The Poet as Printer." In We Met Morris: Interviews with William Morris, 1885-96, edited by Tony Pinkney, 53-55. Reading, UK: Spire Books in association with the William Morris Society, 2005.

_- - " "Thoughts on Education Under Capitalism." In Political Writings: Contributions to Justice and Commonweal, 1883-1890, edited by Nicholas Salmon, 375-78.

_-_. "Useful Work versus Useless Toil." In News from Nowhere And Other Writings, edited by Clive Wilmer, 285-386. London: Penguin Books, 1998.

Putnam, Hilary. "Intelligence and Ethics." In A Companion to Pragmatism, edited by John R. Shook and Joseph Margolis, 267-77. Malden, MA: Blackwell Publishing, 2006.

Putnam, Ruth Anna. “Democracy as a Way of Life.” In John Dewey's Educational Philosophy in International Perspective: A New Democracy for the TwentyFirst Century, edited by Larry A. Hickman and Giuseppe Spadafora, 36-47. Carbondale: Southern Illinois University Press, 2009.

Rousseau, Jean-Jacques. Emile or On Education. Introduction, translation, and notes by Alan Bloom. New York: Basic Books, 1979.

Ryan, Alan. John Dewey and the High Tide of American Liberalism. New York: Norton, 1995.

Sennett, Richard. The Craftsman. London: Penguin Books, 2008.

Sennett, Richard and Cobb, Jonathan. The Hidden Injuries of Class. New York: Norton, 1972.

Sidorkin, Alexander. “John Dewey: A Case of Educational Utopianism.” Philosophy of Education Yearbook (2009): 191-99.

Stemhagen, Kurt. "Dewey as Utopian: Labor Versus Leisure, Mass Media as Democratic Education, and the Future of Public Schooling." Philosophy of Education Yearbook (2009): 200-03.

Williams, William Carlos. Imaginations. New York: New Directions, 1970.

Willis, Paul. Learning to Labour: How Working Class Kids Get Working Class Jobs. Farnborough: Saxon House, 1977.

John Freeman-Moir is Senior Lecturer in the College of Education at the University of Canterbury.

E-mail: john.freeman-moir@canterbury.ac.nz 